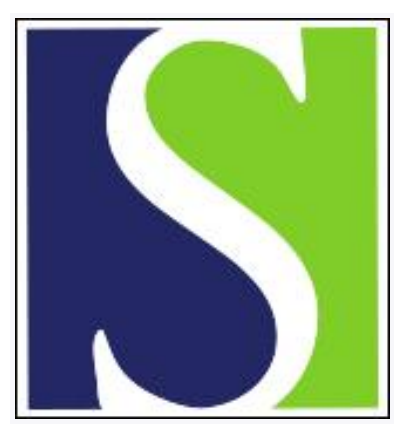

Scand J Work Environ Health 2001;27(1):63-69

https://doi.org/10.5271/sjweh.588

Issue date: Feb 2001

Consequences of workplace bullying with respect to the well-being of its targets and the observers of bullying by Vartia MA-L

Affiliation: Finnish Institute of Occupational Health, Department of Psychology, Laajaniityntie 1, FIN-01620 Vantaa, Finland. maarit.vartia@occuphealth.fi

The following articles refer to this text: 2011;37(3):204-212;

2011;37(4):276-287; 2016;42(1):26-33

Key terms: observer; psychological work environment; stress reaction; well-being; workplace bullying

This article in PubMed: www.ncbi.nlm.nih.gov/pubmed/11266149

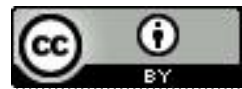




\title{
Consequences of workplace bullying with respect to the well-being of its targets and the observers of bullying
}

\author{
by Maarit A-L Vartia, MA
}

\begin{abstract}
Vartia MA-L. Consequences of workplace bullying with respect to the well-being of its targets and the observers of bullying. Scand J Work Environ Health 2001;27(1):63-69.
\end{abstract}

\begin{abstract}
Objectives This study investigated the effects of workplace bullying and the psychological work environment on the well-being and subjective stress of the targets and observers of bullying.

Methods In a questionnaire study, stress and psychological ill-health were measured, and the causes of reported stress were analyzed for municipal employees ( $N=949,85 \%$ women, $15 \%$ men, mean age 41 years for the men and 40 years for the women).

Results Both the targets of bullying and the observers reported more general stress and mental stress reactions than did respondents from the workplaces with no bullying. The targets also expressed feelings of low selfconfidence more often than did those who had not been subjected to bullying. Being bullied, but also features of one's work, especially haste, excessively difficult tasks and poor goal clarity, predicted the stress reactions reported. Of the single forms of bullying, judging a person's work unjustly or in an offending manner, restricting a person's possibilities to express his or her opinions, and assaulting one's private life were the most clearly connected with all the stress reactions measured. Victim history was associated with feelings of low selfconfidence. The targets of bullying used sleep-inducing drugs and sedatives more often than did the respondents who were not bullied.

Conclusions The study shows that not only the targets of bullying, but also bystanders, suffer when someone is bullied in the workplace. Bullying must therefore be regarded as a problem for the entire work unit and not merely as a problem of the target.
\end{abstract}

Key terms psychological work environment, stress reactions, targets of bullying.

Being bullied at work can be classified as a significant source of social stress at work $(1,2)$. Bullying or mobbing $(1,3)$ refer to situations in which someone is subjected to long-lasting, recurrent, and serious negative or hostile acts and behavior that are annoying and oppressing. In the bullying process targets become unable to defend themselves. Examples of the forms of single negative acts of bullying are negatively gesturing toward or glancing at the target, ignoring the target, refusing to talk or listen to the target, slander, laughter and scorn directed toward the target, and belittling of the target's work.

Many authors have reported a significant association between exposure to workplace bullying and health and well-being. Increased levels of psychological complaints, depression, burnout, anxiety, and aggression, and also psychosomatic and musculoskeletal health complaints have been reported in various studies $(1,2$, 4-7). Among Norwegian blue-collar and white-collar workers, bullying alone accounted for $13 \%$ of the variance in psychological complaints, $6 \%$ of the variance in musculoskeletal problems, and $8 \%$ of the variance in psychosomatic health complaints (5). Symptoms of post-traumatic stress disorder and general anxiety disorder have been identified among interviewed victims of bullying and among patients subjected to bullying (4, $8,9)$. Of the different forms of bullying, an attack on the person's privacy or personal derogation has shown the strongest and most consistent correlation to psychological ill-health $(1,5)$. Bullying has also been reported to be associated with sick leave $(6,10,11)$. Suicidal thoughts and suicides have been reported by some writers as the most extreme consequences of bullying ( 8 , $12,13)$.

1 Finnish Institute of Occupational Health, Department of Psychology, Helsinki, Finland.

Reprint requests to: Ms Maarit Vartia, Finnish Institute of Occupational Health, Department of Psychology, Laajaniityntie 1, FIN-01620 Vantaa, Finland. [E-mail: maarit.vartia@occuphealth.fi] 
In regard to the consequences of bullying, some studies have explored the significance of the duration and frequency of the negative acts $(5,6)$. In a study among labor union members (5), the duration of bullying correlated significantly with psychological, psychosomatic, and musculoskeletal symptoms. In the public sector, those who had been bullied every day or almost every day for 6 months to 2 years were the persons who most often reported feelings of depression (14). It has also been shown that the negative health effects of bullying do not disappear immediately when the negative behavior has stopped or when the person has changed jobs (15).

Workplace bullying can be seen as a process comprising several phases, from aggressive behavior to the victim's exclusion from the workplace and severe trauma $(3,16)$. In this process, all members of the work unit have some role, often the role of observer or onlooker. In studies on bullying at schools, the roles of classmates have been discussed $(17,18)$, but in workplace bullying the roles of the members of the work unit and the effects that bullying have on their health have thus far received very little attention. In a nationwide interview study (15), the observers of bullying reported more health symptoms than those working in workplaces in which no one was bullied; $34 \%$ of those who reported that someone was continuously being bullied at their workplace had sleeping problems, as opposed to $19 \%$ for those who reported no bullying at their workplace. The same trend was also seen, for example, for headache, strain, fatigue, and lack of energy.

Numerous studies have demonstrated the connections between the features of work, work organization, cooperation, and the like and stress reactions (19). It has also been shown that work-related factors (eg, role conflicts, work control, poor flow of information, and haste at work) can promote bullying $(20,21)$. In studies on the effects of workplace bullying on employees' health and well-being, the environmental factors have not, however, been controlled. The relationship between bullying and health has, however, been reported to be moderated (eg, by the victim's self-esteem, social support, and lack of social anxiety) (5).

The primary aim of this study was to investigate the subjective stress and reported symptoms of psychological ill-health among bullied employees and observers of bullying. The health effects of bullying were studied in such a way that the contents and organization of work were also taken into account. Furthermore, the purpose of the study was to examine what forms of bullying have the most detrimental effects on the health of the affected persons. One question is whether not a person who has been a victim of bullying once is more likely to become a victim also at some other workplace. No earlier data on this issue are available. Another objective was to investigate this "victim history" and the connections between it and reported stress symptoms. In addition, the use of sleep-inducing drugs and sedatives by the victims of bullying and absence from work due to bullying was investigated.

\section{Subjects and methods}

The subjects of this study were members of the Federation of Municipal Officials working in a variety of occupations in the municipal sector. Every 35th member of the union was selected from its membership list. Altogether 1577 questionnaires were distributed, and 1037 persons responded (response rate 65.5\%). Eighty-eight of the returned questionnaires were rejected, however, because of the respondent's long-term unemployment or absence from work. The remaining 949 respondents formed the study group. Most of the subjects were employed in office work (48\%), food services and basic services (12\%), technical occupations, fire fighting, harbor or traffic $(12 \%)$, or in social work $(10 \%)-85 \%$ were women and $15 \%$ were men. The mean age of the men was 41 (SD 10.51) years and that of the women was 40 (SD 10.09) years.

\section{Measures}

The following definition of bullying was provided: "Bullying is long-lasting, serious negative action and behavior that is annoying and oppressing. It is not bullying if you are scolded once or someone shrugs his or her shoulders at you once. Negative behavior develops into bullying when it is continuous and repeated. Often the target of bullying feels unable to defend him or herself." The respondents were then asked if they felt themselves subjected to such behavior or if they had observed someone else at their workplace being subjected to this kind of negative treatment. The various forms of bullying were measured using a revised version of the Leymann Inventory of Psychological Terrorization (22). The frequency and duration of negative acts were both assessed with one question, also used by Leymann (23).

Stress and psychological health were measured with the Occupational Stress Questionnaire, developed at the Finnish Institute of Occupational Health $(24,25)$. A definition of stress was first given and the respondent was asked if he or she felt this kind of stress. "Stress means a situation in which a person feels tense, restless, nervous, or anxious, or is unable to sleep at night because his or her mind is troubled all the time. Do you feel this kind of stress these days?" This kind of stress is referred to "general stress" in this paper. The content, construct, and predictive validity of this single-item measure of stress from the Occupational Stress Questionnaire have 
been investigated with 4 research data sets. The single question on stress proved to be valid and was feasible in different measurement contexts at the group level (26). Psychological stress symptoms and mental resources were measured with 14 items, (eg, "Are you depressed?", "Have you been unusually tired lately?", "Are you nervous?", "Do you feel capable and confident?") The response scales were 5-point Likert scales.

The measures of a psychological work environment and the characteristics of work (eg, haste at work, worktasks that are too difficult) were measured with the single items of the Occupational Stress Questionnaire. Victim history, use of sleep-inducing drugs and sedatives, and absence from work because of bullying were each assessed with 1 question.

\section{Statistical analysis}

Factor analysis (maximum likelihood) and varimax rotation were conducted for the psychological stress symptoms and mental resources. The symptoms were grouped into 2 dimensions. The items of these factors were summed, and 2 symptom scales were formed, one being named "mental stress reactions" and the other being "feelings of low self-confidence" (table 1). Differences in the reported symptoms between the study groups were analyzed using ANOVA (analysis of variance) and pairwise t-tests. Cronbach's alpha was computed for the factors that showed that the internal consistency of both factors was high ( $\alpha 0.88$ and 0.78 ). Product-moment correlations (Pearson's r) between the variables were computed to examine the strength of the relations between the single forms of negative acts and the stress reactions measured. A multiple regression analysis was carried out to determine the combination of variables explaining the reported stress and psychological symptoms.

\section{Results}

Ten percent (94 respondents) felt themselves bullied, and 9\% (83 respondents) were observers of bullying. The frequency and duration of negative acts perceived by the targets of bullying are shown in table 2 .

\section{Experienced stress and psychological symptoms}

The experienced stress reactions were analyzed for the following three groups: (i) bullied employees, (ii) observers, (iii) those from workplaces where no one was bullied, the "nonbullied" group. The general stress level of the targets of bullying was high. Some $40 \%$ of the targets experienced rather or very much stress in comparison with $25 \%$ of the observers and $14 \%$ of the nonbullied employees.
Table 1. Factor structure of the mental symptoms and resources.

Factor loadings

Factor 1: mental stress reactions

$\begin{array}{lr}\text { Depressed } & 0.71 \\ \text { Strained } & 0.68 \\ \text { Unusually tired } & 0.68 \\ \text { Nervous } & 0.67 \\ \text { Distressed } & 0.63 \\ \text { Staying awake at nights } & 0.61 \\ \text { Difficulties in falling asleep } & 0.59 \\ \text { Factor 2: feelings of low self-confidence } & \\ \text { Feeling inferior } & 0.75 \\ \text { Feeling helpless } & 0.63 \\ \text { Feeling capable and confident } & -0.57 \\ \text { Feeling lonely } & 0.51\end{array}$

Table 2. Frequency and duration of negative acts, targets of bullying ( $\mathrm{N}=93-94)$.

\begin{tabular}{lc}
\hline & Percent \\
\cline { 2 - 2 } Frequency & \\
$\quad$ Daily or almost daily & 30 \\
Once a week & 16 \\
Less often & 54 \\
Duration & \\
$<6$ months & 14 \\
6 months-2 years & 28 \\
$2-5$ years & 29 \\
$>5$ years & 30 \\
\hline
\end{tabular}

The targets of bullying more often reported general stress, mental stress reactions, and feelings of low selfconfidence than the observers and employees from the workplaces without bullying. The observers of bullying, the bystanders, reported significantly more general stress and mental stress reactions than did the employees from workplaces without bullying. No difference was found between the observers and the nonbullied group, however, in feelings of low self-confidence (table 3 ).

\section{Bullying and work environment as predictors of stress symptoms}

To find an answer to the question "How significant is the effect of bullying and what are the effects of work conditions in causing the reported stress reactions?", 2 regression analyses were conducted, one to determine the meaning of being a target of bullying and the other to clarify the meaning of observing bullying, in relation to the reported health outcomes.

Being a target of bullying was a significant predictor of all the stress symptoms measured (table 4). The features of work were also significant explanatory factors. Although only some features of work were measured, $20 \%$ to $25 \%$ of all the variance of the reported stress symptoms could be explained. Bullying alone accounted for $5 \%$ of the variance in general stress, $8 \%$ 
Table 3. General stress, mental stress reactions, and feelings of low self-confidence experienced by the bullied, the observers, and the nonbullied group.

\begin{tabular}{|c|c|c|c|c|c|c|}
\hline \multirow[t]{2}{*}{ Group } & \multicolumn{2}{|c|}{ General stress } & \multicolumn{2}{|c|}{ Mental stress reactions } & \multicolumn{2}{|c|}{ Feelings of low self-confidence } \\
\hline & Mean & $\mathrm{SD}$ & Mean & $\mathrm{SD}$ & Mean & SD \\
\hline Bullied (B) & 3.23 & 1.09 & 3.00 & 0.75 & 2.68 & 0.81 \\
\hline Observers (O) & 2.83 & 1.12 & 2.56 & 0.80 & 2.31 & 0.68 \\
\hline Nonbullied (Non) & 2.56 & 1.06 & 2.33 & 0.64 & 2.18 & 0.61 \\
\hline $\begin{array}{l}\text { ANOVA } \\
\text { Pairwise t-test }\end{array}$ & \multicolumn{2}{|c|}{$\begin{array}{l}F=27.75 P<.00001 \\
B / O P=0.0100 \\
B / N o n P=0.0001 \\
O \text { Non } P=0.0013\end{array}$} & \multicolumn{2}{|c|}{$\begin{array}{l}F=43.40 P<0.0001 \\
B / O P=0.0001 \\
B / N o n P=0.0001 \\
O \text { Non } P=0.0041\end{array}$} & \multicolumn{2}{|c|}{$\begin{array}{l}F=22.62 P<0.0001 \\
B / O P=0.0005 \\
B / N o n P=0.0001 \\
O \text { Non } P=0.0945\end{array}$} \\
\hline
\end{tabular}

Table 4. Regression analysis for general stress, mental stress reactions, and feelings of low self-confidence, standardized regression coefficients.

\begin{tabular}{|c|c|c|c|c|c|c|}
\hline & \multicolumn{3}{|c|}{ All } & \multicolumn{2}{|c|}{ Not bullied themselves } & \multirow[b]{2}{*}{$\begin{array}{l}\text { Feelings of low } \\
\text { self-confidence }\end{array}$} \\
\hline & $\begin{array}{l}\text { General } \\
\text { stress }\end{array}$ & $\begin{array}{l}\text { Mental stress } \\
\text { reactions }\end{array}$ & $\begin{array}{l}\text { Feelings of low } \\
\text { self-confidence }\end{array}$ & $\begin{array}{l}\text { General } \\
\text { stress }\end{array}$ & $\begin{array}{l}\text { Mental stress } \\
\text { reactions }\end{array}$ & \\
\hline Bullying & $0.11 * * *$ & $0.18^{* * *}$ & $0.13^{* * *}$ & $0.08^{*}$ & $0.07^{\star}$ & 0.03 \\
\hline Haste & $0.29 * * *$ & $0.23^{* * *}$ & 0.03 & $0.28 * * *$ & $0.22 * * *$ & 0.05 \\
\hline Goal clarity & $0.08^{* *}$ & $0.16^{* * *}$ & $0.19 * * *$ & $0.06^{*}$ & $0.13^{* * *}$ & $0.19 * * *$ \\
\hline Excessively difficult tasks & $0.19 * * *$ & $0.21 * * *$ & $0.29 * * *$ & $0.23^{* * *}$ & $0.25 * * *$ & $0.31 * * *$ \\
\hline Amount of joint meetings at the workplace & $0.11 * * *$ & $0.13^{* * *}$ & $0.12^{* * *}$ & $0.13^{* * *}$ & $0.16^{* * *}$ & $0.14^{* * *}$ \\
\hline \multirow[t]{2}{*}{ Changes at work anticipated } & $0.13^{* * *}$ & 0.04 & 0.01 & $0.12^{* * *}$ & 0.02 & 0.02 \\
\hline & $\begin{array}{l}\mathrm{R}^{2}=0.25 \\
\mathrm{R}^{2}\{\mathrm{adj}=0.24\end{array}$ & $\begin{array}{l}R^{2}=0.26 \\
R^{2}\{a d j=0.25\end{array}$ & $\begin{array}{l}R^{2}=0.21 \\
R^{2}\{a d j=0.20\end{array}$ & $\begin{array}{l}\mathrm{R}^{2}=0.23 \\
\mathrm{R}^{2}\{\mathrm{adj}=0.23\end{array}$ & $\begin{array}{l}R^{2}=0.22 \\
R^{2}\{\text { adj }=0.22\end{array}$ & $\begin{array}{l}R^{2}=0.18 \\
R^{2}\{a d j=0.17\end{array}$ \\
\hline
\end{tabular}

${ }^{*} \mathrm{P}<0.05,{ }^{*} \mathrm{P}<0.01,{ }^{* * *} \mathrm{P}<0.001$.

of the variance in mental stress reactions, and $5 \%$ of the variance in low self-confidence. The results also showed that observing bullying is a significant predictor of general stress and mental stress reactions (table 4). A regression analysis was also conducted with age and gender as extra independent variables. Age and gender were not found to be significant predictors of the stress reactions measured.

No clear and parallel relationships were found between the frequency and duration of bullying episodes and the reported stress reactions.

\section{Forms of bullying and different stress reactions}

Some forms of bullying may be more harmful to a target's well-being than others. "Judging a person's work performance wrongly or in an offending manner" was the form most strongly connected with general stress. "Assaulting one's private life" and "judging one's work wrongly" showed the strongest correlation with mental stress reactions. Feelings of low self-confidence were the most strongly connected with "giving a person meaningless tasks" and "restricting a person's possibilities to express his or her opinions" (table 5). Targets of bullying often feel that receiving no tasks or only a very few puts one in a very unpleasant situation. In this study "giving a person very few tasks or none at all" was not, however, significantly associated with any of the stress reactions measured.

The correlations between different forms of bullying were high (table 5). This finding, as well as experiences from the victims' interviews and discussions, showed that, in most cases, the targets of bullying are subjected to many forms of bullying at the same time.

\section{Victim history}

For most of the targets $(79 \%)$ this was the 1 st case of being bullied. One out of 5 targets of bullying reported that they had also been subjected to bullying earlier at some other workplace, $15 \%$ had been bullied once before and $6 \%$ more than once. The victim history was associated with feelings of low self-confidence $(r=0.24$, $\mathrm{P}<0.02$ ). Those who had been bullied once or more than once before more often reported feelings of low selfconfidence than those who were being bullied for the 1st time at the time of the study, although no association existed between victim history and the other stress reactions measured.

\section{Use of sleep-inducing drugs and sedatives and absenteeism}

The bullied employees used both sleep-inducing drugs and sedatives more often than the other subjects 
Table 5. Correlations between single forms of bullying or negative acts and stress reactions among the targets of bullying $(\mathrm{N}=96)$.

\begin{tabular}{lccc}
\hline & $\begin{array}{l}\text { General } \\
\text { stress }\end{array}$ & $\begin{array}{l}\text { Mental stress } \\
\text { reactions }\end{array}$ & $\begin{array}{l}\text { Feelings of low } \\
\text { self-confidence }\end{array}$ \\
\cline { 2 - 4 } & 0.13 & $0.21^{*}$ & $0.28^{* *}$ \\
Treated like air & 0.08 & 0.19 & $0.27^{* *}$ \\
Isolation from others & & & \\
Restricting possibilities & $0.22^{*}$ & $0.21^{* *}$ & $0.31^{* * *}$ \\
to express one's opinions & -0.03 & 0.05 & -0.06 \\
Giving no or very few tasks & 0.14 & $0.25^{*}$ & $0.43^{* *}$ \\
Giving meaningless tasks & $0.34^{* * *}$ & $0.25^{* *}$ & $0.21^{*}$ \\
Judging one's work wrongly & $0.29^{* *}$ & $0.28^{* *}$ & 0.14 \\
Assaulting one's private life & 0.17 & $0.24^{*}$ & $0.23^{*}$ \\
Speaking ill behind one's back & 0.17 & & \\
\hline
\end{tabular}

* $P<0.05,{ }^{* *} P<0.01,{ }^{* * *} P<0.001$.

(table 6). The use of these drugs did not correlate with the duration or the frequency of bullying, nor with the victim history.

Almost 1 out of $5(17 \%)$ bullying victims reported that they had been away from work because of bullying, $10 \%$ had been away several times, and $7 \%$ had been away once.

\section{Discussion}

The present study confirmed the results of earlier studies showing that being bullied at work is a threat to the psychological well-being of bullied employees; the respondents who were subjected to bullying experienced all the measured stress reactions more than the others. It is important, however, to note that bullying at work appears to not only have negative effects on the wellbeing of the victims, but also on the observers of bullying, who reported more general stress and mental stress reactions than those from the workplaces without bullying. Bullying was not connected with the level of the observers' self-confidence.

A central question of this study was how much of this lowering of mental well-being experienced by the targets and observers of bullying is actually the result of bullying and to what extent it is connected with other work environment factors. The study showed that a significant relationship remained between bullying and the reported stress symptoms, both among the targets and among the observers, after the effects of work environment factors had been statistically controlled. Among the observers, the connection was somewhat weaker, which is understandable. In addition to bullying, haste, excessively difficult worktasks, lack of goal clarity, situations in which there were only a few or no joint meetings at the workplace, and forthcoming changes at work were important explanatory variables of general stress and mental stress reactions. Gender and
Table 6. Use of sleep-inducing drugs and sedatives by the targets of bullying, the observers, and those from workplaces without bullying.

\begin{tabular}{lccc}
\hline & $\begin{array}{c}\text { Bullied } \\
(\%)\end{array}$ & $\begin{array}{c}\text { Observers } \\
(\%)\end{array}$ & $\begin{array}{c}\text { Nonbullied } \\
(\%)\end{array}$ \\
\cline { 2 - 4 } & 88 & 90 & 95 \\
$\begin{array}{l}\text { Sleep-inducing drugs } \\
\text { No }\end{array}$ & 13 & 10 & 5 \\
$\begin{array}{l}\text { Yes, occasionally or } \\
\text { regularly }\end{array}$ & 84 & 92 & 97 \\
$\begin{array}{l}\text { Sedatives } \\
\text { No } \\
\text { Yes, occasionally or }\end{array}$ & 16 & 8 & 3 \\
\hline egularly & & \\
\hline
\end{tabular}

Sleep inducing drugs $\quad \chi^{2}=9.76 \mathrm{P}<0.01$

Sedatives $\quad \chi^{2}=28.59 \mathrm{P}<0.001$

age were not connected with any of the stress reactions measured. We can thus conclude that especially becoming a target of bullying, but also observing bullying in one's work unit, is a significant stress factor related to health risk.

Different forms of bullying seemed to lead to different kinds of subjective symptoms. Earlier Zapf et al (1) have shown that attacking a person's private life correlates the strongest with the psychological ill-health of a bullied employee. The present study supported this result and showed that also assessing one's work wrongly or in an offending manner, assigning meaningless tasks, restricting one's possibilities to express his or her opinions, and gossiping behind one's back are associated with mental stress reactions. Assigning meaningless tasks, restricting one's possibilities to express his or her opinions, being treated like air, and isolation from others were the factors most strongly connected with feelings of self-confidence. This is an understandable result, as these forms of bullying in many ways restrict a person's possibilities for social contacts in the work unit. Criticizing one's private life was not, however, associated with the self-confidence of the target.

The frequency and duration of bullying episodes were not connected with the reported symptoms. This finding differs from that of Einarsen \& Raknes (10), who found that the duration of bullying was associated with the reported symptoms. One explanation for this difference may be the small number of victims in the study. As Leymann (6) also pointed out, another explanation can be that there were no differences because the stress level of all the victims was very high.

Some researchers (3) consider that negative treatment can be called bullying when such negative acts occur frequently, at least once a week, over a long period of time (ie, at least 6 months). In this study many employees felt that they themselves were targets of bullying although they had been treated negatively for less than 6 months. They also reported mental stress reactions more often than those who experienced no 
bullying. Due to the small number of bullying victims, it was not possible to conduct an analysis that would take into account both the duration and frequency of bullying episodes at the same time.

Almost $80 \%$ of the targets reported that they were being subjected to workplace bullying for the 1st time. This result supports our experiences from discussions and interviews with victims of bullying, who most often said that bullying starts unexpectedly and that they were being subjected to bullying for the 1st time. The results of the stress reactions and victim history indicate that repeated workplace bullying especially affects feelings of self-confidence negatively. In this study, however, the group of respondents bullied once or more than once before was small, and it was therefore difficult to draw any conclusions about the significance of repeated bullying for well-being. Earlier studies $(6,11)$ have shown an association between bullying and sick leave. In the present study, $18 \%$ of the victims of bullying reported that they had been away from work once or several times due to bullying. This is not very much. Often bullied employees dare not be away from work because absence from work could become a new reason for bullying.

In this study both single-item measures and sum scales were used in measuring psychological health and well-being. Although sum scales are generally considered more valid than single-item measures, validity research has shown that single-item stress measures can be valid on the group level. Long-term conclusions about stress on the individual level cannot be drawn on the basis of only 1 question (26). As Orhede (27) has stated, sum scales can also be strongly blurred or biased.

Although many studies on bullying have been conducted during the past few years, there is still much to be done. Comprehensive, systematic study of all the consequences of workplace bullying, including economic ones, is still needed. We also need more information about both the environmental and personal factors that moderate, for example, the negative health effects of workplace bullying and the different kinds of bullying processes at workplaces. In practice, we have seen that some victims of bullying have fallen seriously ill after 6 months of serious bullying, while others are still working even after 5 to 10 years of bullying.

\section{References}

1. Zapf D, Knorz C, Kulla M. On the relationship between mobbing factors, and job content, social work environment, and health outcomes. Eur J Work Organ Psychol 1996; 2:215-37.

2 Niedl K. Mobbing and well-being: economic and personnel development implications. Eur J Work Organ Psychol 1996;
2:239-49.

3. Leymann H. The content and development of mobbing at work. Eur J Work Organ Psychol 1996;2:165—84.

4. Björkqvist K, Österman K, Hjelt-Bäck M. Aggression among university employees. Aggressive Behav 1994;20:173—84.

5. Einarsen S, Raknes BI, Matthiesen SB, Hellesoy OH. Helsemessige aspekter ved mobbing i arbeidslivet. Modererende effekter av sosial stotte og personlighet [Health aspects of bullying at work: modifying effects of social support and personality]. Nord Psykol 1996;2:116-37.

6. Leymann H. Psykiatriska problem vid vuxenmobbning. [Psychiatric problems in connection with bullying]. Stockholm: Arbetarskyddsstyrelsen, 1992.

7. Einarsen S, Raknes BI. Harassment in the workplace and the victimization of men. Violence Victims 1997;3:247-63.

8. Groeblinghoff D, Becker M. A case study of mobbing and the clinical treatment of mobbing victims. Eur J Work Organ Psychol 1996;2:277-94.

9. Leymann H, Gustafsson A. Mobbing at work and the development of post-traumatic stress disorders. Eur J Work Organ Psychol 1996;2:251-75.

10. Einarsen S, Raknes B I. Mobbing i arbeidslivet [Bullying at work]. Bergen (Norway): University of Bergen, 1991.

11. Kivimäki M, Elovainio M, Vahtera J. Workplace bullying and sickness absence in hospital staff. Occup Environ Med 2000;57:656-60.

12. Ege H. Mobbing in Italy. Paper presented at the Eighth European Congress on Work and Organizational Psychology, 25 April 1997, Verona, Italy.

13. Leymann H. Ingen annan utväg. Om utslagning och självmord som följd av mobbning $\mathrm{i}$ arbetslivet [No other way: about exclusion and suicide as consequences of mobbing at work]. Stockholm: Wahlström \& Widstrand, 1988.

14. Vartia M. The consequences of psychological harassment (mobbing) at work. In: The Psychological Society. III European Congress of Psychology, July, 4-9, 1993: abstract book. Tampere (Finland): The Psychological Society, 1993:139.

15. Sutela H, Lehto A-M. Henkinen väkivalta on koko työyhteisön ongelma [Bullying is a problem of the whole work unit]. Hyvinvointikatsaus 1998;3:18-24.

16. Einarsen $\mathrm{S}$. The nature and causes of bullying at work. Int $\mathbf{J}$ Manpower 1999;1/2:16-27.

17. Fraczek A. Violence and aggression in children and youth: a socio-psychological perspective. Eur Rev 1996;1:75-90.

18. Salmivalli K. Koulukiusaaminen ryhmäilmiönä [Bullying in schools as a group phenomenon]. Tampere (Finland): Gaudeamus, 1998.

19. Karasek RA. Job demands, job decision latitude, and mental strain: implications for job redisign. Adm Sci Q 1979;24: $258-308$.

20. Einarsen S, Raknes BI, Matthiesen SB. Bullying and harassment and their relationships to work environment quality: an exploratory study. Eur J Work Organ Psychol 1994;4: $381-401$.

21. Vartia M. The sources of bullying - psychological work environment and organizational climate. Eur J Work Organ Psychol 1996;2:203-14.

22. Leymann H. Presentiation av LIPT-formuläret. Konstrution, validering, utfall [Presentation of the Leymann Inventory for Psychological Terrorization], Stockholm: Violen inom Praktikertjänst, 1989.

23. Leymann H. Vuxenmobbning på svenska arbetsplatser [Bullying at Swedish workplaces]. Stockholm: Arbetarskyddssty- 
relsen, 1992.

24. Elo A-L, Leppänen A, Lindström K, Ropponen T. Occupational stress questionnaire: user's instructions. Helsinki: Finnish Institute of Occupational Health, 1992.

25. Kivimäki M, Kalimo R. Self-esteem and the occupational stress process: testing two alternative models in a sample of blue-collar workers. J Occup Health Psych 1996;2:187-96.

26. Elo A-L, Leppänen A, Lindström K, Jahkola A. Voidaanko stressiä työssä tutkia pätevästi yhdellä kysymyksellä? [Can stress be studied by a single item measure?] Työ ja Ihminen 1999;3:23-9.

27. Orhede E. On bruken af surveydata i arbejsmiljöundersökelser - et metodstudie [On the use of survey data in work environment studies - a method study]. Köpenhamn: Arbetsmiljöinstituttet, Sociologisk Institut, Köpenhavns Universitet, 1998.

Received for publication: 24 February 2000 